\title{
The Resolution of Post-Election Challenges Under Section 5 of the Voting Rights Act
}

\section{Cynthia Grace Lamar}

Section 5 of the Voting Rights Act of $1965^{1}$ is designed to thwart racially discriminatory election procedures by requiring that the states and subdivisions covered by the Act implement no change in election practice until the Justice Department or the United States District Court for the District of Columbia determines that the change is not discriminatory. As enacted, the statute assigns sole responsibility to the Justice Department for monitoring compliance with this submission requirement. In 1969, the Supreme Court recognized a private right of action under section 5 that allows private citizens to supplement Justice Department oversight. ${ }^{2}$ This private cause of action may be brought in a plaintiff's local district court and allows a plaintiff to challenge an election procedure as a change lacking "preclearance."3 The purview of the local district court is limited; because the statute gives the Justice Department and the district court in Washington exclusive jurisdiction to determine whether a challenged election procedure is discriminatory in purpose or effect, the Supreme Court has restricted local district courts to the procedural question of whether the practice was a change requiring federal approval.

In most private suits, the local district court will enjoin prospectively an unprecleared procedure and require the voting district to use preexisting election practice. However, when a private citizen brings a challenge after an election has been held pursuant to an unprecleared procedure, the court must also decide whether to grant retroactive relief by invalidating the election.

While invalidation is an effective remedy, it is also attended by high costs. Because local district courts are unable to consider the question of discrimination in section 5 suits, their decisions may invalidate elections that are not in any way discriminatory. This result is contrary to the pur-

1. Pub. L. No. $89-110$, tit. I, $\S 5,79$ Stat. 437,439 (1965) (codified as amended at 42 U.S.C. $\S \S$ 1971, 1973c (1982)).

2. Allen v. State Bd. of Elections, 393 U.S. 544 (1969).

3. Federal approval of a voting procedure is termed "preclearance." While not a statutory term, it is widely used in the literature. 
poses of the Act, as well as the interests of both minority voters and covered jurisdictions.

This Note focuses on local federal courts' remedial decisions in postelection, private challenges. It argues that these courts should be allowed to reach the question of discrimination in resolving challenged elections so that they can award appropriate relief. Central to this argument is the assertion that invalidation under section 5 is warranted for discriminatory elections but not for those in which the only established violation was a failure to preclear. ${ }^{4}$ Although changes in election procedure by covered jurisdictions remain presumptively suspect, these jurisdictions should not be subject to a different standard for the imposition of the invalidation remedy than the rest of the country. ${ }^{5}$ Section 5 is an extraordinary provision designed to combat discrimination in voting; extraordinary remedies thereunder should be linked to that purpose.

Section I of this Note describes the statutory scheme for preclearance and the judicially created role of local district courts in section 5 enforcement, and explains the significance of the invalidation remedy in section 5 suits. Section II reveals the disparate remedial approaches and irreconcilable results in section 5 suits produced by the current limitation on local district court jurisdiction. Section III proposes that local district courts be allowed to consider the question of discrimination for the limited purpose of informing their remedial decision regarding the specific election in question. It does not suggest, however, that a district court's resolution of the election immediately in dispute should relieve the voting district of its responsibility to submit the change itself to the Justice Department for approval. Thus, enlargement of local district court jurisdiction should ameliorate the present difficulties of post-election challenges without compromising the statutory goal of uniform preclearance standards.

4. In 1986, a district court in Alabama invalidated a statewide election when a private citizen brought a section 5 action to challenge illegal conduct by a candidate. The candidate, the state attorney general, improperly encouraged cross-over voting by Republicans on the eve of the election. Henderson v. Graddick, 641 F. Supp 1192 (M.D. Ala. 1986) (three-judge panel), appeal dismissed, 479 U.S. 1023 (1986). The attorney general's conduct was clearly politically motivated-polls had shown that he would receive $84-88 \%$ of Republican cross-over votes, $641 \mathrm{~F}$. Supp. at 1197 -but the court never found that cross-over voting would dilute the strength of minority votes. In fact, it regarded the question of discrimination as beyond its inquiry. Id. at 1198. Nevertheless, the court ordered the state Democratic Party not to certify the results of the election because the change could have affected the outcome of the election. Id. at 1204. While the court's response was proper under section 5 as it is presently enforced, this Note contends that invalidation without a showing of discrimination is not justified by the Act's goal.

5. Invalidation is traditionally reserved for situations of egregious discrimination. See infra notes 24-27 and accompanying text. 


\section{The Present Operation of Segtion 5}

\section{A. The Statutory Preclearance Scheme}

Section 5 of the Voting Rights Act $^{6}$ requires those electoral jurisdictions with a history of discrimination, as defined by section 4 of the Act, ${ }^{7}$ to obtain federal preclearance for all changes in voting practice or procedure before implementation. ${ }^{8}$ Federal preclearance takes the form of an administrative finding by the Attorney General or a declaratory judgment by the D.C. District Court that the change has neither the purpose nor the effect of discriminating against racial or certain language minorities. ${ }^{9}$

The declaratory judgment procedure for preclearance has rarely been used; ${ }^{10}$ instead, covered jurisdictions have preferred the more informal administrative procedure. ${ }^{11}$ Covered jurisdictions must routinely submit all

6. 42 U.S.C. $\S 1973 c(1982)$.

7. Pub. L. No. $89-110$, tit.1 $\$ 4,79$ Stat. $437,438-39$ (1969) (codified as amended at 42 U.S.C. 1973b (1982)), triggers section 5 "coverage" of a given locality if the jurisdiction maintained a voter eligibility test in the presidential elections of 1964,1968 , or 1972 , and if voter registration or turnout was less than $50 \%$ in the previous presidential election. The Act originally covered Alabama, Virginia, Georgia, Louisiana, Mississippi, and South Carolina, as well as one county in Arizona and Hawaii and 39 counties in North Carolina. H.R. REP. No. 387, 91st Cong., 1st Sess. 3 (1969). Coverage was extended in 1975 to include jurisdictions with over five percent language minorities that, as of November 11, 1982, had election materials printed only in English, and in which less than $50 \%$ of the eligible population voted in the 1972 election. Voting Rights Act Amendments of 1975, Pub. Law No. 94-73, 89 Stat. 400 (codified at 42 U.S.C. $\$ 1973 \mathrm{c}$ (1982)). For a list of jurisdictions covered by section 5, see U.S. Comm'N ON CIvil Rights, The Voting Rights ACT: UNFulfilled Goals 24-27 (1981).

8. Jurisdictions "covered" by section 5 of the Act may not enact any changes in voting procedure or qualifications different from those in effect on November 1, 1964, without securing federal approval that the proposed enactment "does not have the purpose and will not have the effect of denying or abridging the right to vote on account of race or color . . ." 42 U.S.C. $\$ 1973$ c (1982).

9. Id. The standard that has been applied in section 5 cases is "nonretrogression," 28 C.F.R. $\S$ 51.54 (1987); the change need not improve the minority voting situation but must not diminish minority voting strength. See e.g., Beer v. United States, 425 U.S. 130 (1976) (creating retrogression test for use under section 5); Lockhart v. United States, 460 U.S. 125 (1983) (as long as change not retrogressive, it need not have any ameliorative effect).

Section 2 of the Voting Rights Act, which applies nationally and guarantees fifteenth amendment rights, was amended in 1982 to incorporate a standard prohibiting discriminatory results, Pub. L. No. $89-110, \S 2,79$ Stat. 437, 437 (1965) (codified as amended at 42 U.S.C. 1972 (1982)), and some have argued that section 5 should adopt the results test as well. See, e.g., Note, Getting Results Under Section 5 of the Voting Rights Act, 94 Y ALE L.J. 139, 140 n.10 (1985) (section 5 preclearance standard should be results test that looks for social and institutional factors suggesting racial vote dilution). The most recent Justice Department regulations conclude that a voting procedure that would clearly violate section 2 should not receive preclearance, 28 C.F.R. $\S 51.55(b)(2)(1987)$, implying that the results standard has been incorporated into section 5 .

10. See Keady \& Cochran, Section 5 of the Voting Rights Act: A Time for Revision, $69 \mathrm{Kx.} \mathrm{L.J.}$ $741,750-54$ (1981). As of 1981, only twenty cases had been filed in the District of Columbia from which sixteen published opinions resulted. Id. at 753 . By contrast, from 1965 to June 30,1986 , the Justice Department reviewed 112,184 submissions; 12,646 submissions were made in the first six months of 1986 alone. See U.S. DeP'T of Justice, Civil Rights Div., Complete Listing of Objections Pursuant to Section 5 of the Voting Rights Act of 1965 (Sept. 30, 1986).

For the sake of convenience, this Note will usually refer only to the Justice Department's preclearance procedure.

11. See H. Ball, D. Krane \& T. Lauth, Compromised Compliance 88 (1982) (noting frequent informal communications between local attorneys and Justice Department to facilitate preclearance) (hereinafter $\mathrm{H}$. BALL]. Although administrative preclearance began as a "Congressional afterthought" created to resolve procedural uncertainty expeditiously, it became "a permanent and the 
changes $^{12}$ and must provide the Justice Department's Voting Division with all requested information regarding the voting procedure. The burden of proof is on the submitting jurisdiction to show that the change is free of discriminatory purpose or effect. ${ }^{13}$ A letter of approval, or the Attorney General's failure to object within the consideration period, ${ }^{14}$ "preclears" the procedure and allows the jurisdiction to implement the change. ${ }^{15}$ An objection letter from the Attorney General blocks the change. ${ }^{16}$

\section{B. The Private Right of Action}

The Act as passed gave the Justice Department sole responsibility for monitoring compliance with the submission requirement. ${ }^{17}$ By 1969, the Supreme Court was convinced that Justice Department oversight alone was insufficient, and in Allen v. State Board of Elections ${ }^{18}$ recognized a private right of action under section $5 .{ }^{19}$ The Allen scheme allows private plaintiffs to challenge in their local district courts changes covered by sec-

most important segment of the Voting Rights Act." Keady \& Cochran, supra note 10, at 755-56.

12. Coverage has been extended to "changes" regarding reapportionment, e.g., Wise v. Lipscomb, 437 U.S. 535, 542 (1978); Beer v. United States, 425 U.S. 130, 133 (1976); annexations, e.g., Richmond v. United States, 422 U.S. 358, 378-79 (1975); boundary alterations, e.g., Berry v. Doles, 400 U.S. 379, 388 (1971); changes from ward to at-large elections, e.g., id. at 394; location of polling places, e.g., id. at 388; candidate qualifications, e.g., Hadnott v. Amos, 394 U.S. 358 (1969); Allen v. State Bd. of Elections, 393 U.S. 544, 569 (1969); and alterations in procedure for casting write-in ballots, e.g., id. at 570 .

Some have argued that such extensive coverage exceeds the intentions of the statute's drafters and amounts to harassment of covered jurisdictions. See, e.g., 116 CoNG. REC. S6157-58 (1970) (statement of Sen. Dole) (most submissions involve inconsequential changes); 121 CoNG. REC. S24,732 (1975) (enlargement of alcove near registrar's office required preclearance; hallway could not be widened for 60 days); id. at 24,733 (detailed list of covered changes); Keady \& Cochran, supra note 10, at 745 ("Indeed, there would seem to be few state actions that relate to the electoral process that would not be subject to the proscriptions of section 5."); cf. Roman, Section 5 of the Voting Rights Act: The Formation of an Extraordinary Federal Remedy, 22 AM. U.L. REv. 111, 131 (1972) (recommending that certain changes be excluded from coverage).

13. 42 U.S.C. $\$ 1973$ c (1982).

14. The statutory period for administrative consideration is 60 days, 42 U.S.C. $1973 \mathrm{c}$ (1982), but the Justice Department regulations provide for an expedited proceeding under unusual circumstances. 28 C.F.R. $§ 51.34$ (1987). If the Justice Department is not convinced of the procedure's acceptability within the 60 day consideration period, it may request further information from the jurisdiction before the 60 days have run. This extends the consideration period. See, e.g., Georgia v. United States, 411 U.S. 526 (1973) (department's request for further information tolls additional 60 day period).

15. The Attorney General's decision not to object is not subject to judicial review. Morris v. Gressette, 432 U.S 491 (1977). Some have argued that this insulation jeopardizes minority rights. See, e.g., Binion, The Implementation of Section 5 of the Voting Rights Act: A Retrospective on the Role of Courts, 32 W. Pol. Q. 154, 172 (1984) (Morris decision does not protect interest of racial minorities because it preserves autonomy of Attorney General in face of discriminatory change).

16. An objection will be interposed not only if the Attorney General finds that the change is discriminatory, but also if the Attorney General is unable to determine that the change is free of discriminatory purpose or effect or if the evidence of discrimination is conflicting. 28 C.F.R. $\S$ 51.52(c) (1987).

17. 42 U.S.C. $\$ 1973 \mathrm{c}(1982)$.

18. 393 U.S. 544 (1969).

19. Id. at 557 (Attorney General's limited resources may render "[t]he guarantee of $\S 5 \ldots$ an empty promise unless the private citizen [is] allowed to seek judicial enforcement of the prohibition."). These private actions are referred to as "coverage" suits. 
tion 5 but not precleared. Because the statute grants exclusive jurisdiction over the discrimination question to the D.C. District Court or the Attorney General, the Allen court denied local district courts jurisdiction to determine whether challenged changes were discriminatory and limited their authority to the question of whether the procedure was a change that should have been precleared. ${ }^{20}$

Ordinarily, the decision of the local district court in coverage suits is straightforward: Any change in procedure that lacks the necessary preclearance will be enjoined "unless or until" it is approved. ${ }^{21}$ The remedial decision is much more significant, however, when private challenges are brought after an election has been held pursuant to an unprecleared change. In such cases, the validity of the election is necessarily called into question and the court must decide whether nullification of the election is warranted in addition to the prospective injunction. At the same time, these courts lack jurisdiction to reach the issue of discrimination. They thus cannot weigh the competing interests, outlined below, that should inform their remedial decision.

\section{Implications of the Invalidation Remedy}

Federal invalidation of state elections is an equitable remedy that was first employed in the reapportionment and civil rights cases of the 1960 's. ${ }^{22}$ From the beginning, courts have regarded invalidation as clearly within their equitable powers to fashion effective relief, but have acknowledged that the remedy must be cautiously applied. Invalidation provides sweeping remedy to a tainted election, ${ }^{23}$ but does not come without costs to the affected jurisdiction and its citizens. These costs include the significant expenditure of additional time and resources required to conduct a new election, ${ }^{24}$ a debilitating impact on the community's political

20. See id. at 559. The Allen Court also interpreted the statute to require a three-judge panel to resolve these coverage suits. Id.

21. Id. at 561 .

22. See, e.g., Starr, Federal Judicial Invalidation as a Remedy for Irregularities in State Elections, 49 N.Y.U. L. REv. 1092 (1974) (tracing relatively recent development of invalidation remedy). One of the first courts to employ this remedy was the Fifth Circuit in Hamer v. Campbell, 358 F.2d 215 (5th Cir.), cert. denied, 385 U.S. 851 (1966); see also Gardner \& Ebers, Federal Protections of Individual Rights in Local Elections, 13 J. MARSHaLl L. REv. 503, 504-05 (1980) (tracing federal court entrance into state electoral processes).

23. Starr, supra note 22, at 1102-03; see also id. at 1095 ("Ordering a new election is, in some respects, the ultimate judicial cure for illegalities which taint the political process.").

24. See Perkins v. Matthews, 400 U.S. 379, 408 (1971) (Black, J., dissenting). Justice Black describes invalidation in a section 5 challenge where no discrimination had been proven as

a 'shotgun' sanction, damaging all of the candidates and all of the people in [the jurisdiction].

Useless campaign expenses would have to be borne by both white and black candidates. And the town, through property or sales taxes imposed on all citizens, black or white, rich or poor, Id. would have to collect tax money to pay the expenses of a new election. 
processes, ${ }^{25}$ and the antidemocratic effects of a rerun election. ${ }^{28}$ Accordingly, courts and commentators have urged that the remedy be limited to instances of substantial discrimination. ${ }^{27}$

The Supreme Court recently expressed this same concern, requiring that local district courts undertake an "equitable weighing process" before an election is overturned in a section 5 challenge. ${ }^{28}$ However, the Allen scheme for private actions obstructs this remedial decision because local district courts are not permitted to weigh the costs of invalidation against the extent, or even the presence, of discrimination. Requiring courts to resolve challenged elections without considering the presence of discrimination jeopardizes the interests of all citizens of a covered jurisdiction. On the one hand, the electorate may be denied effective relief if the court is unable to recognize a discriminatory situation and declines to overturn the election; on the other hand, the jurisdiction and its citizens may suffer unnecessarily the costs of a rerun election if a court invalidates an election for a coverage violation that had no discriminatory effects. A survey of post-election suits reveals that dissimilar remedial approaches invite these incongruous results.

\section{The Current Resolution of Post-Election Suits}

Courts considering election challenges are faced with the choice of nullifying the election or allowing it to stand. ${ }^{29}$ In section 5 suits, courts either have made this decision with no information regarding the presence

25. See Note, State Candidacy: Requirements, Rights and Remedies, 116 U. PA. L. REv. 347, 352 (1967) (invalidation subjects state to "greatest disruption which judicial intervention can work."). 26.

[D]etrimental side effects which the invalidation remedy may have on the local political scene are that incumbents cannot govern as vigorously as otherwise possible; that the costly election machinery must be resuscitated for the rerun; that political candidates are forced to rejuvenate moribund campaigns; and that the voters are asked to renew their interest in the same contest with the same candidates.

Starr, supra note 22 , at 1128 .

27. See, e.g., Taylor v. Monroe County Bd. of Supervisors, 421 F.2d 1038, 1042 (5th Cir. 1970) (invalidation remedy "undesirable at best"); Hamer v. Ely, 410 F.2d 152, 156 (5th Cir.) (invalidation "properly reserved for cases involving serious violations of voting rights"), cert. denied, 396 U.S. 942 (1969); Bell v. Southwell, 376 F.2d 659, 662 (5th Cir. 1967) (invalidation "[d]rastic, if not staggering" remedy); MacGuire v. Amos, 343 F. Supp. 119 (M.D. Ala. 1972) (invalidation harsh); Perkins v. Matthews, 336 F. Supp. 6, 9 (S.D. Miss.) (invalidation reserved for "gross and indefensible racially discriminatory practices"), on remand from 400 U.S. 379 (1971); Smith v. Paris, 257 F. Supp. 901, 905 (M.D. Ala. 1966) (invalidation should be limited to "the most extraordinary of circumstances"), modified, 386 F.2d 979 (5th Cir. 1967); Gardner \& Ebers, supra note 22, at 507 n.19 (blatant violation of federally protected right such as racial discrimination necessary for federal court intervention); Starr, supra note 22, at 1123 (only substantial misfeasance justifies imposition of costly invalidation remedy).

28. NAACP v. Hampton County Election Comm'n, 470 U.S. 166, 183 n.36 (1985) (reversing lower court judgment and remanding for remedial decision because district court had "never engaged in the equitable weighing process necessary to determine whether failure to submit a covered change for preclearance requires that an election be set aside").

29. Courts may also order interim relief, allowing the results of an election to stand until the Attorney General has passed on the merits of the change. This "certification" alternative is discussed infra notes $47-57$ and accompanying text. 
of discrimination or have sought to ascertain the fairness of the election indirectly or through extra-statutory considerations. As this Section indicates, none of these approaches advances section 5's goal of preventing discriminatory election procedures. Uninformed decisions are arbitrary, while indirect attempts to detect discrimination fail to inform the courts' decision adequately. The prerequisites to section 5 relief set up by some district courts transgress the statutory scheme and may discourage private suits. Thus, the present limitation on local district court jurisdiction interferes with the fair resolution of election challenges and impedes accomplishment of the Act's goal-the elimination of voter discrimination.

\section{A. Uninformed Decisions}

Some courts have based their remedial decision solely on a jurisdiction's failure to seek preclearance, without considering the election's fairness. Courts declining to order retroactive relief at this juncture ${ }^{30}$ may deny minority voters effective relief because the challenged election procedure may actually have been unconstitutionally discriminatory. ${ }^{31}$ Conversely,

30. See MacGuire v. Amos, 343 F. Supp. 119 (M.D. Ala. 1972) (court declined to void retroactively election held pursuant to unprecleared procedure); United States v. Garner, 349 F. Supp. 1054 (N.D. Ga. 1972) (court did not overturn election results but allowed those elected to serve until next municipal election even though Attorney General interposed objection); McGill v. Ryals, 253 F. Supp. 374 (M.D. Ala.) (court declined to overturn election held pursuant to unprecleared procedure because exigencies not extraordinary), appeal dismissed, 385 U.S. 19 (1966); Toombs v. Fortson, 241 F. Supp. 65 (N.D. Ga. 1965) (court declined to void retroactively election held pursuant to unprecleared procedure), modified, 275 F. Supp. 128 (N.D. Ga.), affd 384 U.S. 210 (1966); see also Crowell, Possible Surprises Ahead-Preclearance Under the 1965 Voting Rights Act, ScHool L. Bull., Spring, 1986, at 1, 5 ("Generally, a court will not set aside elections held under the unprecleared change but will enjoin only future enforcement of the change."); $c f$. Binion, supra note 15, at 164-65 (discussing uncertainty regarding retroactive relief among district courts and hesitancy to impose invalidation for changes not amenable to preclearance process).

31. See Roman, supra note 12 , at 132 (prospective relief alone fails to fulfill congressional intent regarding changes with substantial effect on election); Wallace, Runoff Primaries: Is There a Discriminatory Result?, 2 J.L. \& PoL. 369, 395 (1985) (prospective relief alone fails to provide effective relief to discriminatory election).

Plaintiffs could, of course, bring another suit under section 2 of the Voting Rights Act or the Fifteenth Amendment to prove that the election was discriminatory and should be overturned. However, section 2 and Iffeenth amendment suits place extensive burdens of proof on the plaintiff. See, e.g., id. at 403 (section 2 suits not viable alternative for minority plaintiffs because plaintiff bears burden of proof and because "such litigation is a complex, expensive and lengthy process which is beyond the resources of many potential litigants"); $c f$. Allen v. State Bd. of Elections, 393 U.S. at 556 n.2 (inadequacy and difficulty for minority plaintiffs of suits under Fifteenth Amendment prompted passage of Voting Rights Act). Thus, because the burden of disproving discrimination is on the defendant jurisdiction in section 5 litigation, it is clearly to the plaintiff's advantage to resolve an election in a section 5 suit. Furthermore, the Allen Court expressly provided that private section 5 challenges should be brought in the local district court to spare private plaintiffs the cost of litigating in the District of Columbia. Id. at 559-60; see also infra note 60. The value of the private right of action for these plaintiffs is greatly reduced, however, if these local courts decline to grant fully effective relief because they are unable to reach the election's merits. See Binion, supra note 15, at 164 ("In offering only a declaratory judgment, the [District] Court left the political party essentially unpunished for past illegal acts and unrestricted as to its immediate future actions. Not only did the Court fail to rectify the existing situation of non-compliance with Section 5 , but it has also put little premium on future compliance.") (discussing MacGuire v. Amos, 343 F. Supp. 119 (M.D. Ala. 1972)).

If only prospective injunctive relief were available, a jurisdiction's incentive to preclear when an 
other courts that consider only a jurisdiction's failure to preclear overturn elections on that basis alone. ${ }^{32}$ Automatic invalidation is as undesirable as a wholesale refusal to nullify elections in coverage suits. While routine invalidation might deter deliberate failures to preclear, ${ }^{33}$ many changes in election procedure are spontaneous occurrences not amenable to the preclearance process ${ }^{34}$ or are innocuous changes with no discriminatory purpose or effect. ${ }^{35}$ Also, given the costs imposed on the entire voting district $^{36}$ and the high standard for the imposition of invalidation in other contexts, ${ }^{37}$ the remedy is inappropriate when the change lacks discrimina-

election is imminent would be diminished-an effect most injurious if the change were indeed discriminatory. The jurisdiction would suffer other consequences for failing to preclear the procedure, however, because the jurisdiction would be unable to "bail out" of section 5 coverage. "Bailout" refers to exemption from section 5's submission requirement. This exemption is permanent, and depends on the ability of the jurisdiction to show, inter alia, that it: (1) has not used a discriminatory device in the electoral process, 42 U.S.C. $\$ 1973 \mathrm{~b}(\mathrm{a})(1)(\mathrm{A})(1982)$; and (2) that it has complied fully with the preclearance requirement, id. $\$ 1973 \mathrm{~b}(\mathrm{a})(1)(D)$, (E) (1982). For a complete listing of requirements for bailout, see Voting Rights Act Amendments of 1982, Pub. L. No. 97-205, § 2(b), 96 Stat. 131, 131 (codified at 42 U.S.C. $\$ 1972 b(a)(1-9)$ (1982)); see also Boyd \& Markman, The 1982 Amendments to the Voting Rights Act: A Legislative History, 40 WASH. \& LEE L. REv. 1347, 1374-75 (1983) (describing changes in bailout procedure to make bailout realistic possibility for covered jurisdictions).

32. Brown v. Post, 279 F. Supp. 60 (W.D. La. 1968), exemplifies the per se approach to invalidation. In Brown, the court ordered a new election although it found that the officials acted in good faith and the wrongdoing had no discernible effect on the election. For a discussion of the Brown approach, see Starr, supra note 22, at 1122 (describing Brown as stating "the broadest possible rule of invalidation" under section 5, standing for proposition that "[s]o long as there exist possible discriminatory actions by election officials, the election must be undone."); see also Henderson v. Graddick, 641 F. Supp. 1192 (M.D. Ala.) (court invalidated election for unprecleared change without showing of racial discrimination because court was barred from considering effect of change on election), appeal dismissed, 479 U.S. 1023 (1986); United States v. Garner, 349 F. Supp. 1054 (N.D. $\mathrm{Ga}$. 1972) (assuming invalidation required whenever change clearly requiring federal approval implemented without preclearance); United States v. Kemper County, No. 74-65(c) (S.D. Miss. Nov. 21, 1974) (court voided election in which county had converted from single-member to at-large districting without obtaining section 5 preclearance); United States v. Twiggs County, No. 2825 (M.D. Ga. Jan. 31, 1973) (same).

Some commentators have supported the per se invalidation approach. See, e.g., Binion, supra note 15, at 164-65 ("failure to obtain the clearance should be sufficient grounds for judicial remedies which disallow and void the practice albeit after it has occurred."); Derfner, Racial Discrimination and the Right to Vote, 26 VAND. L. REv. 523, 577-78 (1973) (same); Roman, supra note 12, at 132 (suggesting section 5 be amended to require nullification of elections held pursuant to unprecleared changes). But see Perkins v. Matthews, 400 U.S. 379, 408-09 (1971) (Black, J., dissenting) (cmphasizing injustice of imposing high costs of invalidation on jurisdiction when no discrimination established); Starr, supra note 22, at 1123 (mechanical nature of per se rule violates equity's balancing of countervailing considerations and risks unwise results due to lack of causal connection between illegality and election results).

33. "IS]alutary effects may indeed flow from ... consistent use of an invalidation order where the particular wrongdoing takes place in a context of intransigent, obstinate refusals by the states or localities fully to carry out responsibilities in a constitutionally appropriate way." Starr, supra note 22 , at 1123.

34. See Binion, supra note 15, at 164-65 (rules governing political candidates often not formal changes "enacted, then made operative," but rather are ad hoc and nonexistent prior to use, and thus are not subject to prophylactic prevention by section 5 ).

35. Of the 112,184 submissions made to the Justice Department from 1965 to June 30, 1986, only 1,404 changes were objected to by September 30, 1986. See U.S. Dep'T of JusTrCE, CiviL Righrs Div., supra note 10; see also supra note 12 (discussing extent of changes covered and noting that virtually every change, no matter how ministerial, is covered).

36. See supra notes 24-26 and accompanying text.

37. See supra note 27 and accompanying text. 
tory purpose or effect. ${ }^{38}$ Per se nullification for a failure to preclear denies covered jurisdictions the equitable weighing of costs traditionally guiding the application of the invalidation remedy. ${ }^{38}$

\section{B. Improper Prerequisites to Retroactive Relief}

Some courts shrink from ordering a remedy based solely on their determination that a covered change was not precleared. Instead, they employ extra-statutory tests for retroactive relief. A principal method is to consider whether the change was one implemented over a previous Justice Department objection. ${ }^{40}$ This approach is helpful but not sufficient. Not all changes are submitted, ${ }^{41}$ and changes that occur during an election, or are effectuated by someone other than the jurisdiction's authorities, are not amenable to the preclearance process. ${ }^{42}$

Courts hearing section 5 actions have also imposed prerequisites that controvert the clear congressional intent that covered voting districts, and not private citizens, bear the burden of proof under section $5 .{ }^{43}$ For exam-

38. See, e.g., Perkins v. Matthews, 400 U.S. 379, 408 (1971) (Black, J., dissenting) ("In the absence of affirmative proof of racial discrimination, I believe it would be an abuse of any remedial discretion that may be vested in the federal judiciary to compel [the jurisdiction] to hold a new election."); id. at 406 (Black, J., dissenting) ("Only after discrimination has been established does the Federal Government have the power under the Fourteenth Amendment and the Supremacy Clause to interfere with the State's conduct of its own affairs."); Allen v. State Bd. of Elections, 393 U.S. 544, 572 (1969) (new election should not be ordered because "the discriminatory purpose or effect of these statutes, if any, has not been determined by any court"); see also Gardner \& Ebers, supra note 22, at $507 \mathrm{n} .19$ ("It is not enough to attack the state scheme without having a factual situation which is almost a blatant violation of federally protected rights."); MacCoon, The Enforcement of the Preclearance Requirement of Section 5 of the Voting Rights Act of 1965, 29 CatH. U.L. REv. 107, 124 (1979) (minor or inconsequential changes do not justify invalidation); Starr, supra note 22, at 1123 ("Even upon a finding of substantial misfeasance, the willingness of courts to enter summarily a remedy sure to work significant hardship on the community is open to question absent [widespread discriminatory conduct].").

39. See, e.g., Starr, supra note 22 , at 1123 (per se invalidation obstructs equitable balancing and is inappropriate against "isolated instances of misconduct in which officials acted in good faith or in which forcing a rerun election would be an academic exercise because of the lack of causal connection between the illegality and the election results").

40. See, e.g., United States v. Garner, 349 F. Supp. 1054 (N.D. Ga. 1972) (special election ordered where county switched to at-large districting despite Attorney General objection); United States v. Meriwether County, No. 74-35N (N.D. Ga. Sept. 30, 1974) (same); United States v. Twiggs County, No. 2825 (M.D. Ga. Jan. 31, 1973) (special election ordered under similar circumstances). In Allen, 393 U.S. at 571-72, the Court named as a relevant factor whether the jurisdiction could reasonably be expected to have known that holding the election violated section 5 . In Perkins, 400 U.S. at 396, the Court identified as other relevant factors: the nature of the changes complained of, whether it was reasonably clear at the time of the election that the changes were covered by section 5 , and whether or not preclearance had been sought. For a discussion of prerequisites to retrospective relief, see MacCoon, supra note 38, at 124.

41. See, e.g., H. BALL, supra note 11, at 86, 166-67.

42. See, e.g., Binion, supra note 15, at 164 ("But many changes in rules governing candidacies . . - are not formal changes at all and as such are difficult to prevent through reliance on Section 5 because they do not exist until after they have occurred.") (emphasis in original); see also supra note 12.

43. 42 U.S.C. \& 1973c (1982); see also MacCoon, supra note 38, at 124-26 (discussing importance of leaving burden of proof on defendant jurisdiction; criticizing criteria for retroactive relief as imposing improper burdens of proof on plaintiff). 
ple, at least one court has attempted to discourage politically motivated suits under the private right of action by requiring that plaintiffs make a "good faith allegation" of racial discrimination as a minimal prerequisite to the suit. ${ }^{44}$ Similarly, courts have denied retroactive relief because of a plaintiff's lack of pre-election diligence. ${ }^{45}$ These inappropriate prerequisites employed by courts unwilling to order invalidation based solely on the failure to preclear would be obsolete if these courts could consider the discrimination issue directly. ${ }^{46}$

\section{The Certification Alternative}

The Supreme Court has acknowledged that a coverage determination does not afford a district court access to sufficient information to resolve a challenged election. ${ }^{17}$ In response, the Court has suggested a "certification" 18 procedure in which the district court postpones its remedial decision until the jurisdiction can submit the change to the Justice Department. $^{49}$

44. See, e.g., Beatty v. Esposito, 439 F. Supp. 830 (E.D.N.Y.) (requiring good faith allegation of racial discrimination to state a claim in section 5 enforcement action in order to prevent use of section 5 for purely political reasons), modified, 439 F. Supp. 830 (E.D.N.Y. 1977); Gangemi v. Sclafani, No. 74-C-1269 (E.D.N.Y. Sept. 4, 1974) (same), affd, 506 F.2d 570 (2d Cir. 1974); see also MacCoon, supra note 38, at 121 (requirement of good faith allegation of racial discrimination apparently an effort to prevent use of section 5 for political reasons when plaintiffs present no legitimate question of discrimination against protected minorities).

45. See e.g., Hadnott v. Amos, 394 U.S 358 (1969); McGill v. Ryals, 253 F. Supp. 374 (M.D. Ala.), appeal dismissed, 385 U.S. 19 (1966); cf. Tucker v. Burford, 603 F. Supp. 276 (N.D. Miss. 1985) (preelection diligence not mandatory for post-election relief, but plaintiff's good faith must be decided on case-by-case basis); Hamer v. Campbell, 358 F.2d 215, 222 (5th Cir. 1966) (noting that invalidation proper because "[ $\mathrm{t}] \mathrm{his}$ is not a case where an election is challenged for the first time after it is held").

46. Some courts have disregarded the present statutory limits on their jurisdiction and considered the issue of discrimination. Not surprisingly, these courts have been reversed for overreaching their proper scope of review. See, e.g., United States v. Board of Supervisors, 429 U.S. 642 (1977) (reversing district court for considering constitutional implications of violation); Perkins v. Matthews, 400 U.S. 379, 434 (1971) (district court exceeded permissible scope of review by considering merits of change).

47. See Allen v. State Bd. of Elections, 393 U.S. 544, 572 (1969); see also supra note 27 and accompanying text (citing arguments that invalidation should be ordered only in face of discrimination affecting outcome of election).

48. The term "certification" does not appear in the cases or literature discussing section 5 remedies, but rather is a convenient label this Note uses to connote the Court's suggestion that district courts cede the discrimination question to the Justice Department.

49. Perkins v. Matthews, 400 U.S. 379, 396-97 (1971) (Court first suggested that "in certain circumstances ... . it might be appropriate to enter an order affording local officials an opportunity to seek federal approval and ordering a new election only if local officials fail to do so or if the required federal approval is not forthcoming."); $c f$. NAACP v. Hampton County, 470 U.S. 166 (1985) (ordering similar certification scheme); Berry v. Doles, 438 U.S. 190 (1978) (ordering Perkins procedure).

It is not clear precisely how the Court intended this certification procedure to operate because it has been formulated differently in the several cases setting it out. The Berry Court directed that if approval were granted, "the matter [would] be at an end," 438 U.S. at 193, language suggesting that the election should stand. If the Attorney General objected to the change, however, the Berry Court said only that the appellants could renew to the district court their request for new elections, id., implying that invalidation would not be required, but would remain at the district court's discretion. Conversely, the Hampton County Court apparently intended that objection by the Attorney General would mandate invalidation, 470 U.S. at 183 ("[I]f approval is not forthcoming, the results of the . . 
Although some courts have adopted this certification procedure, ${ }^{80}$ it has two serious drawbacks. First, the certification approach delays the remedial decision. The administrative preclearance process invariably requires

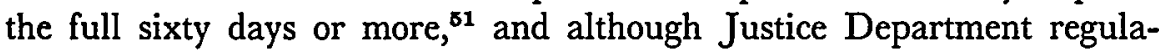
tions allow the voting district to request an expedited procedure, a quick turnaround is not guaranteed..$^{\mathbf{2}}$ In any event, a district court would not be able to engage in the "equitable weighing process" of all relevant factors required by the Supreme Court until the Attorney General had returned a decision. ${ }^{\text {.3 }}$

A second and more critical flaw in the certification scheme is its limited value to a reviewing district court. Because the Attorney General's response usually consists of little more than a yes or no answer, ${ }^{\mathrm{B4}}$ certification does not adequately inform a court's decision. The Justice Department has acknowledged that the administrative process does not approach the thoroughness of judicial fact-finding. ${ }^{\mathrm{s}}$ Indeed, some courts and com-

clection should be set aside."), while the Attorney General's approval would not "end the matter," as in Berry, but would constitute only one of several factors influencing the district court's remedial decision. 470 U.S. at 183 ("If, however, the Attorney General determines that the changes had no discriminatory purpose or effect, the District Court should determine, in the exercise of its equitable discretion, whether the results of the election may stand.").

Thus, the Supreme Court's conflicting directives leave doubt as to whether either objection or approval by the Attorney General necessitates a particular result or if the remedial decision remains entirely at the district court's discretion. A second ambiguity is whether the certification procedure is required for a suit involving a post-election challenge, or is merely available to the district court if it desires the Justice Department's opinion. Perkins suggested certification in some circumstances, but Hampton County implied that certification was required in post-election challenges, 470 U.S. at 183 n.36. If the certification procedure is not mandatory, it is still possible for the district court to remedy elections blindly. To preclude that possibility, if courts are not allowed to rule on the question of discrimination as urged here, Congress should at a minimum mandate a certification procedure for post-election suits to avoid the blind invalidation or approval of elections.

50. See, e.g., Heggins v. City of Dallas, 469 F. Supp. 739 (N.D. Tex. 1979) (mem.) (enjoined election results until Attorney General decision); United States v. Board of Comm'rs, No. 76-M-1086 (N.D. Ala. Feb. 27, 1979) (allowing post hoc submission of challenged procedure before final remedy); United States v. Board of Trustees, No. SA-78-CA-84 (W.D. Tex. Mar. 29, 1978) (same); see also cases cited in MacCoon, supra note 38, at 122 n.109; id. at 122-23 (noting preference of some district courts to enjoin results of election until final determination of section 5 claim on merits in Justice Department).

51. See, e.g, Keady \& Cochran, supra note 10, at 775 (decisions over 100 days late in $68 \%$ of submissions).

52. See supra note 14.

53. See NAACP v. Hampton County Elections Comm'n, 470 U.S. 166, 183 n.36 (1985) ("[T]he determination whether failure to submit the change requires that the election be set aside. . . must be made by the District Court, after the Attorney General has passed on the substantive nature of the change."); see also Henderson v. Graddick, 641 F. Supp. 1192, 1201-02, 1203 (M.D. Ala. 1986) (the word "preclearance" for submission of change after election is misnomer; under facts of this case, for court to stay its hand until Attorney General has opportunity to study racial impact of change would entail too much delay), appeal dismissed, 479 U.S. 1023 (1986).

54. See H. BALL, supra note 11 , at 133 (once documents reporting voting change have been processed, Chief of Voting Section mails letter to local governmental unit notifying it that U.S. Attorney General either "does not interpose any objection" or "interposes an objection"); id. at 258-62 (reproducing sample Justice Department communication to submitting jurisdiction); see also Keady \& Cochran, supra note 10, at $784 \mathrm{n} .197$ (criticizing Attorney General's decisions not to preclear as undocumented and unaccountable).

55.

Unlike court proceedings, administrative review under Section 5 - which is by statute limited 
mentators have questioned the accuracy and efficacy of the administrative preclearance process in general. ${ }^{56}$ Hence, while an indication from the Attorney General of a change's discriminatory potential would certainly aid the court's remedial decision, it does not supplant a district court's own review of the full circumstances of the election. ${ }^{57}$ Despite the Voting Rights Act's stated goal of eliminating discrimination in voting, there is presently no satisfactory means by which local district courts can take discrimination into account in ruling on elections challenged under section 5.

\section{Proposed Role for Local District Courts in Post-Election Ghallenges}

Congress should amend section 5 to give local district courts resolving post-election challenges jurisdiction to consider the issue of discrimination once they have determined that the challenged procedure is covered by section 5. The courts' remedial decisions should be made on an expedited basis to minimize the costs of delay, and the burden of proof should remain on defendants. Although objections have been raised in the past to an expanded role for local district courts, this narrow revision would enhance rather than undermine minority rights under section 5 .

to 60 days upon receipt of all necessary information-does not include the kind of hearing procedures that provide for the full presentation of evidence and rebuttal evidence by contesting parties and others interested in the proceedings. There is no formal record developed with findings of fact and conclusions of law announced at the end by the Attorney General. 52 Fed. Reg. 486, 487 (1987) (commentary to proposed Subpart F, Procedures for the Administration of section 5 of the Voting Rights Act of 1965).

56. See, e.g., City of Rome v. United States, 446 U.S. 156, 205 n.17 (1980) (Powell, J., dissenting) (" $[N]$ o senior officer in the Justice Department-much less the Attorney General-could make a thoughtful, personal judgment on an average of twenty-five preclearance petitions per day. Thus, important decisions made on a democratic basis . . . are finally judged by unidentifiable employees of a federal bureaucracy, usually without anything resembling an evidentiary hearing.").

For a detailed account of the criticisms levelled against the efficacy of the administrative preclearance process in Congress, see Keady \& Cochran, supra note 10, at 754-59; see also id. at 756 (describing preclearance process as "fraught with difficulties which could not have been anticipated in 1965"); McClellan, Fiddling With the Constitution While Rome Burns: The Case Against the Voting Rights Act of 1965, 42 LA. L. REv. 5, 19, 28 (1981) (administrative preclearance unmanageable; broad scope of section 5 has created "massive burden" on Justice Department).

Not only the efficacy, but also the accuracy of the Justice Department's preclearance procedures has been questioned. See Keady \& Cochran, supra note 10, at 773-75 ("paraprofessionals who possess neither demographic/statistical skills nor legal training" make the "initial (and normally upheld) determinations with respect to whether the proposed change has a discriminatory purpose or effect"); see also Binion, supra note 15, at 173 ("[t]he major problem facing the Civil Rights Division has been the gathering of accurate information to insure that . . . it has had sufficient data for assessing the legality of the submitted changes.").

The preclearance process itself should not be abandoned, see, e.g., Keady \& Cochran, supra note 10 , at 780 (recommending retention of modified preclearance procedure), but these well-documented inadequacies in the administrative process support the argument made here that district courts could better give equitable consideration to the discriminatory implications of a challenged election in an expeditious hearing.

57. See, e.g., Keady \& Cochran, supra note 10, at 758-59 (noting "the impropriety of vesting what is essentially a judicial function in an administrative body not accompanied by procedural safeguards"). 


\section{A. Overcoming Past Objections to District Court Jurisdiction}

This proposal answers the two objections that have been raised in the past to allowing local district courts to reach the question of discrimination-the loss of centralized preclearance and a mistrust of Southern federal district judges.

First, members of Congress and commentators have insisted that enforcement of the preclearance process must be centralized to develop expertise in one decisionmaking body and to assure uniform application of the provision. ${ }^{68}$ Allowing district courts to reach the issue of discrimination before deciding whether or not to overturn an election would not interfere with the Justice Department's virtually exclusive control over which procedures receive preclearance. ${ }^{68}$ Because local district courts would consider the presence and magnitude of discrimination in the election for the sole purpose of fashioning an appropriate remedy, they would not "preclear" any election procedure. ${ }^{60}$

A second, more sensitive impediment to expanding participation by local district courts in the enforcement of section 5 stems from Congress' original decision to direct all litigation under section 5 to the District of Columbia: Congress suspected that federal district judges in the South might undermine effective enforcement of the statute. ${ }^{61}$ Whether there remains any continuing basis for this apprehension is certainly questionable. ${ }^{62}$ Twenty three years have passed since the Voting Rights Act and its

58. See, e.g., Keady \& Cochran, supra note 10, at 749-50 (uniformity of interpretation was principal rationale for original decision to limit jurisdiction of section 5 declaratory judgment actions to District of Columbia); id. at 750-51 (uniformity argument relied upon in 1970 and 1975 extensions of the Act to maintain centralized jurisdiction).

59. The revision suggested by this Note involves only those changes challenged in a local district court after an election has been held under the challenged procedure. Thus, local district courts would never consider the merits of changes which have not yet affected an election. Rather, they would enjoin those changes and direct voting districts to submit them for preclearance. See supra text accompanying note 21 .

60. Also, while the District of Columbia court could rule on the issue of discrimination in elections challenged under section 5 , limiting all litigation over the merits of the change to that court curtails the effectiveness of the private right of action. The Allen Court directed that private actions be brought in the local district court expressly to avoid forcing individual plaintiffs to travel to the District of Columbia to litigate.

[T] he individual litigant will often not have sufficient resources to maintain an action easily outside the district in which he resides, especially in cases where the individual litigant is attacking a local city or county regulation. Thus, for the individual litigant, the District of Columbia burden may be sufficient to preclude him from bringing suit.

Allen v. State Bd. of Elections, 393 U.S. 544, 559-60 (1969).

61. See, e.g., 121 CoNG. REc. 16267 (1975) (Rep. Butler charging that centralized jurisdiction not motivated by desire for expertise in District of Columbia but "political bias" against Southern judges); id. at 16283 (Rep. Kindness claiming jurisdictional limits were insult to Southern judiciary); see also, McClellan, supra note 56, at 77 (describing denial of jurisdiction to local district court judges as "one of [the Act's] more egregious and discriminatory provisions"). For an overview of the congressional debate on the issue of the distrust of Southern federal judges, see Keady \& Cochran, supra note 10, at 751-52 nn.53-58 and accompanying text.

62. See, e.g., Keady \& Cochran, supra note 10, at 788 (recommending substantive jurisdiction in the local district courts over whole of preclearance process because "it is time-indeed long past time-to invoke the full authority of federal judges throughout the United States in an effort to realize 
scheme of enforcement were created in response to extreme and seemingly intractable discrimination in election practices. While the importance of protecting minority voting rights remains undiminished, the assumptions upon which the Act originally rested should not be above reconsideration. Because the foregoing review of post-election suits suggests that rather than protecting minority rights, the lack of substantive jurisdiction in the local district courts undermines the ability of private plaintiffs to obtain effective relief under section 5 , the role of district court judges should be reappraised.

It is obvious that federal trial judges in districts covered by section 5 have jurisdiction, along with all federal district courts in the country, to adjudicate claims under the Fifteenth Amendment and under section 2 of the Act. ${ }^{83}$ These same judges are surely appropriate to consider the merits of section 5 cases where the plaintiff's burden is lighter. ${ }^{64}$ Furthermore, this Note suggests that the three-judge district court panel required by the Allen decision for coverage suits ${ }^{\mathrm{es}}$ remand the remedial decision to a single judge court ${ }^{86}$ so that the district court's remedial decision would be subject to intermediate appellate review, bringing an additional level of judicial scrutiny to the resolution of the election challenge. ${ }^{67}$

Finally, it must be stressed that the scheme proposed here does not increase a district court's opportunity to hinder the enforcement of section 5 . District court judges presently resolve challenged elections; this revision seeks only to increase the accuracy of that decision by allowing district courts to reach the issue of discrimination. ${ }^{88}$ This would facilitate appropriate remedies in post-election suits without diminishing the protection of minority rights. ${ }^{68}$

the fundamental objectives of section 5 ").

While evidence was presented at the Congressional Hearings on the 1982 Amendments to the Voting Rights Act that despite progress, vestiges of discrimination remain in voting and registration practices, see Boyd \& Markman, supra note 31, at 1361-63 \& n.85, 1372 n.117, the record does not reveal allegations that federal district judges in covered jurisdictions discriminate against minority voting rights.

63. See supra note 9 (scope of section 2 action); see also Keady \& Cochran, supra note 10, at 751 n.53 (Southern judges decide desegregation and civil rights cases, yet do not have jurisdiction to resolve question of discrimination under section 5).

64. If Congress resists revising the local district court's role because it fears unfair treatment of discrimination suits, it should study these judges' established track records in other cases. In addition, because the coverage of section 5 has been extended beyond its original Southern boundaries, see Yoste, Section 5: Growth or Demise of Statutory Voting Rights?, 48 Miss. L.J. 818, 820 n.18 (1977) ("The original provisions pointedly applied to six southern states . . . but have since been expanded to cover discrimination against language minorities ... ."); see also 28 C.F.R. $\$ 51$ app. (1987) (complete list of covered jurisdictions), a convenient yardstick exists against which the fairness of postelection determinations in the South could be measured.

65. Allen v. State Bd. of Elections, 393 U.S 544, 559 (1969).

66. See infra note 72 and accompanying text.

67. The decisions of three-judge panels of the district courts are subject to direct review by the Supreme Court, 28 USC $\S 1253$ (1982), while a determination by a single-judge court could be reviewed by the appropriate court of appeals.

68. See infra notes 70-85 and accompanying text.

69. Other commentators have urged more radical revisions than those suggested here. See, e.g., 


\section{B. The Remedial Procedure}

Congress should amend the enforcement provisions of the Voting Rights Act so that once a district court presented with a section 5 challenge to an election has determined that the change was one covered by the Act, it may proceed to determine whether the election process was discriminatory. ${ }^{70}$ Given the burden placed on the court system by suits requiring three judge panels, ${ }^{71}$ Congress could provide that the remedial decision in a post-election suit be remanded to a single judge court. ${ }^{72}$ This arrangement would bring the additional benefit of intermediate appellate review, since the decision of a single judge district court would be appealed to the appropriate court of appeals. ${ }^{\text {.3 }}$

Because delay in resolving a challenged election is costly to all parties, resolution of these suits should be expedited. ${ }^{74}$ To that end, this Note does not recommend that local district courts undertake the "complex, expensive and lengthy" evidentiary hearing often entailed by Fifteenth Amendment election discrimination suits in making their remedial decisions. ${ }^{75}$ Rather, Congress could provide for an expedited proceeding in postelection suits under section $5 .^{76}$ Such a uniform procedure should resolve the current disparity of approach and results in these remedial decisions.

Alternatively, plaintiffs could rely on proceedings for expedited review already available in the federal district courts, such as the procedure for a preliminary injunction provided in Federal Rule of Civil Procedure 65. ${ }^{77}$

Boyd \& Markman, supra note 31, at 781 (recommending nationwide application of section 5, with responsibility for preclearance process itself given to local district courts); McClellan, supra note 56, at 77 (suggesting jurisdiction for lower federal district courts over all section 5 litigation, including preclearance of proposed changes).

70. The coverage suit a plaintiff may bring in a local district court, recognized in Allen v. State Bd. of Elections, 393 U.S. 544 (1969), while well-established case law, has not been codified by Congress. See 42 U.S.C. § 1973c (Supp. III 1986). Congress should amend section 5 to include the private right of action and provide that, in post-election challenges, local district courts should determine whether or not the election was tainted by discriminatory process. Further suggestions for implementing this amendment are discussed infra notes 72-85 and accompanying text.

71. See Allen v. Bd. of Elections, 393 U.S. 544, 561 (1969).

72. Some courts have remanded questions in section 5 challenges to single-judge courts. See, e.g., Bond v. White, 508 F.2d 1397, 1400 (5th Cir. 1975) ("This procedural alternative [of remanding to a single-judge court] minimizes the burden that the three-judge court requirement imposes on the fedcral judiciary."); see also Yoste, supra note 64 , at 840 \& n.161 (district courts have "tak[en] their cue from ritual exhortations about the burdens inherent in three-judge courts reiterated in Allen, ... [and] have advocated remanding issues tangential to coverage to single-judge courts").

73. See Allen, 393 U.S. at 561-62 ("[A] direct appeal .... to this Court ... depriv[es] us of the wise and often crucial adjudications of the courts of appeals.").

74. See supra notes 24-26 and accompanying text.

75. See Wallace, supra note 31 , at 403.

76. See, e.g., Keady \& Cochran, supra note 10, at 783 (recommending actual preclearance in local district court and suggesting priority setting in district court for section 5 actions with a statutory right of mandamus to insure promptness and an expedited appeal granted as a matter of right to either party to the litigation).

77. On motion for a preliminary injunction, the court considers whether the injury to plaintiff that would occur in the absence of the injunction is irreparable. See T. CoYNe, Rules of Crvil Procedure for THE UNITEd States District Courts Rule 65(a), at 695-96 (1987); see also Auburn News Co. v. Providence Journal Co., 504 F. Supp. 292, 296 (D.R.I. 1980) ("The decision to 
Because the established standard for the invalidation of an election is egregious discrimination, a court should be able to detect such invalidity within the scope of a preliminary injunction hearing. In cases of uncertainty, the Rules allow a court to order a full trial on the merits. ${ }^{78}$

The burden of persuasion should remain on the defendant jurisdiction. This is consistent with the statute's goal of placing responsibility for compliance on the covered jurisdictions and the Allen Court's goal of encouraging minority plaintiff participation. ${ }^{79}$ While it is the responsibility of the jurisdiction to submit all relevant information and disprove discrimination in a preclearance determination, ${ }^{80}$ it is clearly inappropriate to depend on the defendant's presentation alone to inform the district court of the likelihood of discrimination in a post-election challenge. Instead, the court could appoint, at the initiation of the coverage suit, a special master to study the circumstances of the election and, if a coverage violation were found, to present findings to the court regarding any discriminatory impact on the election. ${ }^{81}$

While this proposal does not contemplate an exhaustive study of the procedure and its effects on the election, egregious cases of discrimination warranting invalidation should be discovered by the district court's investigation. Intentional discrimination could be considered evidence of "egre-

issue a preliminary injunction traditionally rests upon an examination of four factors: 1) the likelihood Plaintiffs will suffer irreparable harm; 2) the balance of this harm with the harm Defendants will suffer if they are enjoined; 3) the probability Plaintiffs will succeed on the merits; and 4) the public's interest in issuing an injunction."), rev'd on other grounds, 659 F.2d 273 (1st Cir. 1981), cert. denied, 455 U.S. 921 (1982). The temporary injunction procedure would facilitate the expedited resolution of a challenged election in which the district court considers the substantive validity of the election.

Orders granting temporary injunctions must set forth specific reasons for granting the order and the acts sought to be restrained. FED. R. CIV. P. 65(d). Thus, the resolution of election challenges under section 5 could be monitored by those concerned with the fairness of local district courts.

78. FED. R. GIV. P. 65(a)(2) (consolidation of hearing with trial on the merits). A full trial would not bring considerable, if any, time savings over the certification procedure, but certification was also criticized for failing to give the court appropriate substantive information. See supra notes 54-57 and accompanying text. Nevertheless, judicial review would still bring the advantage of enabling the court to issue an equitable remedy fully informed of the merits of the violation.

79. See Allen v. State Bd. of Elections, 393 U.S. 544, 559-60 (1969).

80. See MacCoon, supra note 38, at 124 (important that defendant bear burden of proof in section 5 actions); see also supra note 43.

81. The special master could work with the plaintiff in preparing a report in order to incorporate the plaintiff's perceptions of discrimination in the election.

Federal courts have authority to appoint special masters under Rules 53 and 70 of the Federal Rules of Civil Procedure and the inherent power of courts. Rule 53 gives courts the authority to appoint trial-stage special masters, while Rule 70 refers to the appointment of "some other person" to perform specific acts on behalf of a party. See Levine, The Authority for the Appointment of Remedial Special Masters in Federal Institutional Reform Litigation: The History Reconsidered, 17 U.C. DAvis L. REv. 753, 756 (1984). Rule 53(a) grants courts the power to appoint special masters in any pending action, and allows special masters to make accountings or assist in fact-finding, to hold hearings, and to compel testimony and the production of documents. See id. at 758 .

A special master is generally "an experienced private attorney, a retired judge or a law professor or other professional to whom a federal court delegates frontline responsibility on a pro hoc vice basis." Id., at 754 n.4. For examples of the appointment of special masters pursuant to Rule 53, see id., at 760 n.23. 
gious misconduct" sufficient to call for invalidation, but, as in other discrimination cases, ${ }^{82}$ the absence of intent should not stop the court from overturning an election tainted with substantial constitutional infirmity.

The court's ruling on the validity of the election should have no preclearance effect: ${ }^{83}$ neither should its decision be subject to review by the Justice Department. Rather, its remedial decision should be a ruling on the effects the change has had on the election itself, and appeals should proceed through the federal court system. Local election officials should be required to submit the questioned procedure to the Justice Department for preclearance scrutiny, ${ }^{84}$ however, and the district court could retain continuing jurisdiction over the election challenge to entertain subsequent motions by the plaintiff based on considerations arising out of the Attorney General's determination. ${ }^{85}$

82. See supra note 27 (discussing standard for federal invalidation of state elections); see also MacCoon, supra note 38, at 126 (noting one standard for invalidation in section 5 cases requires finding that illegality was "gross, spectacular, and wholly indefensible").

If the court finds that the election was grossly discriminatory, invalidation should be the expected result. The court should order a new election according to preexisting voting procedures and should require the jurisdiction to submit the change in procedure, and any proposed alternative, to the Attorney General for approval. See infra note 85.

83. The local district court's inquiry would be for the sole purpose of considering whether the challenged procedure has a discriminatory purpose or effect that warrants the costs of invalidation. All changes would still be prospectively enjoined by the local district court, which should order the jurisdiction to submit the change for Justice Department scrutiny, regardless of the outcome of the private suit.

84. Mandatory submission of changes giving rise to post-election challenges, although not presently required, would serve as a backup measure against procedures whose discriminatory effect was not discovered in the district court. In this way, the revised procedure for handling post-election suits would provide courts with information crucial to a fair remedial decision without compromising the exclusive jurisdiction of the Justice Department over the preclearance process or ignoring concerns that local district courts will treat plaintiffs' claims unfairly, apprehensions discussed supra text accompanying notes $58-67$.

85. If the submitted change, found discriminatory by the local district court, were to be approved by the Attorney General, the procedure could be implemented in the next election. This seems a very unlikely occurrence, since the district court would have found evidence reasonably indicating the presence of substantial discrimination, and since even indecision regarding a change submitted to the Attorney General results in an objection. See supra note 16. Nevertheless, since the district court retains the discretion under this proposal to invalidate an election for egregious misconduct regardless of discriminatory impact, the complaint could rarely be heard that the district court abused its discretion in invalidating the election. What is intended here is that discrimination be a factor heavily weighed in, not a condition precedent to, the nullification of an election. Thus, this scheme is careful not to interfere with the invalidation of any election abridging the constitutional rights of citizens. The purpose of the approach suggested here is not to avoid the invalidation of elections in general, but only of those for which the presence of discrimination has not been determined by a court.

If the local district court upheld an election, finding insufficient evidence of discrimination or egregious misconduct to warrant invalidation, but the change were subsequently objected to by the Attorney General, the court, having retained jurisdiction over the election challenge until the Justice Department's decision was rendered, could reconsider the validity of the election in light of the Attorney General's decision and call a special election if appropriate. See United States v. County Comm'n, 425 F. Supp. 433 (S.D. Ala. 1976) (suggesting similar course of action), affd, 430 U.S. 924 (1977). A special election would presumably be warranted if the procedure in question affected the outcome of the election. See MacCoon, supra note 38, at 124 (invalidation should be reserved for situations in which outcome of election affected by unprecleared change).

While calling a special election under these circumstances is no less disruptive than under the present scheme, see supra notes 23-27 and accompanying text (pointing out high costs of invalidation and insisting such costs not be blindly imposed), this Note's goal is still accomplished: The court 


\section{Advantages of the Proposed Revision}

This Note's proposal offers several advantages over the present procedure for resolving post-election challenges. Most importantly, the local district court's remedial decision will be informed by a factual finding regarding the existence of discrimination. This will avoid the blind imposition of the costly invalidation remedy or the inadvertent approval of discriminatory elections. ${ }^{86}$ Because submission to the Attorney General of all procedures giving rise to a post-election suit will be mandatory, there should be no loss of uniformity in procedures receiving ultimate approval, and such double scrutiny should identify virtually all discriminatory changes. The local district court's expedited hearing should prove not only more efficient but also more informative than the "certification" procedure. Allowing district courts to review directly the issue of discrimination in post-election challenges should increase uniformity in both approach and result in these suits and insure that remedial orders in section 5 suits correspond to the underlying violations.

\section{Conclusion}

The resolution of challenged state and local elections by federal courts is a delicate proceeding with far-reaching effects on the jurisdiction and electorate involved. Local district courts hearing election challenges under section 5 should be neither expected nor allowed to base their remedial decisions on inadequate substantive information. The goal of section 5 is to prevent discrimination in elections. Local district courts should be fully equipped to fulfill that goal.

considers whether discrimination was present in ruling on the validity of the election, aided by a more uniform and expeditious procedure than the Supreme Court's certification scheme. Also, it is assumed that the temporary injunction hearing in the local district court would detect most grossly discriminatory situations so that the calling of special elections would be rare.

86. This revision brings the added benefit of curing the action's susceptibility to politically motivated abuse, see supra note 44 and accompanying text (discussing courts' attempts to discourage suits brought not on grounds of discrimination but for political reasons). There would be little incentive for a plaintiff to wait until after an election to challenge a previously discovered or inconsequential change in hopes of overturning an unfavorable result when the change did not affect the outcome of the election in a discriminatory manner. 